\title{
Application of the Theory of Planned Behavior in Predicting US Residents' Willingness to Pay to Restore Degraded Tropical Rainforest Watersheds
}

\author{
Elizabeth A. Obeng ${ }^{1}$, Kwame A. Oduro $^{1}$ \& Beatrice D. Obiri ${ }^{1}$ \\ ${ }^{1}$ CSIR-Forestry Research Institute of Ghana, Kumasi, Ghana \\ Correspondence: Elizabeth A. Obeng, CSIR-Forestry Research Institute of Ghana, P. O. Box UP 63, Kumasi, \\ Ghana. Tel: 233-3220-60121.E-mail: eobeng@csir-forig.org.gh
}

Received: September 22, 2019

Accepted: November 14, 2019

Online Published: November 28, 2019

doi:10.5539/jsd.v12n6p62

URL: https://doi.org/10.5539/jsd.v12n6p62

\begin{abstract}
This study assessed US residents' willingness to pay (WTP) to restore degraded tropical rainforest watersheds using predictors from the theory of planned behavior (TPB) in an experimental approach. Responses from a random sample of over 1000 US respondents were analyzed using a logistic regression with willingness to pay as the intended behavior predicted by attitudes, subjective norms, perceived behavioral control, and complementary explanatory variables. Subjective norm was the strongest of all the variables and the strongest TPB predictor of WTP. Other statistically significant variables predicting WTP included direct experience with the resource and support for environmental groups. Age, gender and education also significantly predicted WTP. Overall, 22 percent of respondents were willing to make an annual monetary contribution ranging from US\$30.00 to US\$ 150.00 through increase in income tax for five years. The economic value for the restored tropical rainforest watershed was estimated at US\$ 146.32 per household per year.
\end{abstract}

Keywords: theory of planned behavior, willingness to pay, tropical rainforest watershed, ecological restoration, payment for ecosystem services

\section{Introduction}

Tropical rainforests provide a multitude of ecosystem services that substantially contribute to human well-being (Millennium Ecosystem Assessment, 2005). Tropical rainforests offer fundamental ecological functions at multiple ecological scales ranging from impacts to global carbon cycles to local rainfall regimes (Houghton, 2012; Wunder, 2001).Tropical rainforests are a major reservoir of genetic diversity of plant and animals although covering only about 7\% of the earth's land surface (Food and Agriculture Organization, 2015; Jonathan, Onyekwelu, Reinhard, \& Bernd, 2007). Despite their importance, tropical rainforests continue to be converted to other land uses. According to the Food and Agriculture Organization (2015), per capita area of tropical forests has declined from 0.8 ha to 0.6 ha from 1990 to 2015 .

Payments for forest conservation, among the growing array of payments for ecosystem service (PES) schemes, aim to motivate a change in forest owner behavior by internalizing non-market benefits that forests provide through conditional financial compensation (Engel, 2008; Jack, 2008; Wunder, 2005, 2015; Obeng, Aguilar, \& Mccann, 2018). As a financial mechanism, PES drive attitudinal change by rewarding forgone opportunity costs associated with ecosystem preservation (Moreno-Sanchez, Maldonado, Wunder, \&Borda-Almanza, 2012; Obeng, Aguilar \& McCann, 2018).PES mechanisms offer a direct link between beneficiaries of ecosystem services and providers of such services. Increasing awareness of the global consequences of local tropical forest deterioration has opened the door for new initiatives where local tropical conservation compensated by distant co-beneficiaries as illustrated by the establishment of the United Nations' Initiative on Reducing Emissions from Deforestation and Forest Degradation, plus, conservation, sustainable management of forests and enhancement of forest carbon stocks (UN-REDD+) and Clean Development Mechanism (CDM) projects (Bond et al., 2009; United Nations Framework Convention on Climate Change (UNFCC), 2007; McAfee, 2012). To-date application of payments for forest conservation programs have shown potential to reduce deforestation and prevent forest degradation, particularly the extirpation of timber-value species (e.g., Alix-Garcia, Shapiro \& Sims, 2012; Mohebalian, \& Aguilar, 2015, 2018; Robalino, \& Pfaff, 2013). 
Watersheds constitute some of the most commonly-targeted ecosystems by PES programs (Lin, 2014). Watersheds play an elemental role in water purification, provision and maintenance of suitable habitat for diverse aquatic and terrestrial species, while buffering against floods, droughts, and erosion (Calder \& Aylward, 2006; Calder, Smyle \& Aylward,2007).Multiple watershed PES schemes have been implemented and new ones continue to emerge as evidence strongly supports the cost-effectiveness of this conservation mechanism (Chichilnisky \& Heal, 1998; Ernst, 2004; Hack, Kosmus, Kräuter \& Somarriba, 2013; Kreye, Adams \& Escobedo, 2014; Postel\& Thompson, 2005; Stubbs, 2014, Obeng et al., 2018).Past research has elicited the value derived through voluntary payments to enhance water quality and wildlife habitat conditions among direct users (Lin, 2014; Moreno-Sanchez, et al.,2012; Mueller, 2014) but has neglected other indirect and non-use values. Distant beneficiaries of ecosystem services e.g. in the US, may likely be willing to participate in a PES program and pay landowners of tropical rainforests motivated by existence, bequest and option values (Obeng et al., 2018).

In this study, we aimed to assess predictors of willingness to pay (WTP) to restore a degraded tropical rainforest watershed. WTP constitutes a behavioral intention that can be explained by decision-makers' psycho-social conditions such as attitudes, values, beliefs and norms (Clark, Kotchen, \& Moore, 2003; Obeng \&Aguilar, 2018; Kang, Stein, Heo\& Lee, 2012; Ryan \& Spash, 2010). The Theory of Planned Behavior (TPB) offers an analytical framework to help explain how specific behaviors are influenced by the value an individual place on the behavior, the ease with which it can be performed, the views of significant others, as well as the perception that the behavior remains within the individual's control(Ajzen, 1989, 1991; Ryan \&Carr, 2010). We focused on WTP for the restoration of tropical forest watersheds among US residents because of multi-scalar benefits ranging from local to global communities and opportunities to expand conservation payments from developed to developing nations based on the principles of the total economic values concept. We relied on an experimental approach to elicit WTP among US residents for restoration of degraded tropical rainforest watersheds to establish that linkage and capture values that might not be limited to direct uses due to proximity but option, indirect and non-use values (existence, bequest, altruistic (Obeng, 2017)).

\section{Theoretical Framework}

The theory of planned behavior (TPB) offers a tested theory to frame WTP choices for environmental initiatives (Ajzen \& Peterson 1989; Fielding, McDonald \& Louis, 2008; Harris, Driver, \& McLaughlin, 1989; Liebe, Preisendörfer \& Meyerhoff, 2011; López-Mosquera \& Sánchez, 2012; Pouta \& Rekola, 2001). As an extension of the theory of reasoned action, the TPB offers a psycho-social model of human behavior that considers motivations, attitudes, self-interest and rational choices (Figure 1). The TPB links one's beliefs and behavior and posits that attitude toward a behavior, subjective norm, and perceived behavioral control influence behavioral intention. Behavioral intention specifies the motivational factors that influence behavior and provides an indication of an individual's readiness to perform a given behavior (Ajzen, 1991). Attitude towards the behavior offers an indication of people's evaluation of the behavior and reflects the extent to which an individual appraises a given behavior as favorable or unfavorable. Subjective norm is the social pressure to perform or not to perform a given behavior and expresses an individual's perception about the particular behavior, which is influenced by the judgment of significant others (e.g., parents, spouse, friends, colleagues). Perceived behavioral control refers to the perceived ease or difficulty of performing particular the behavior of interest (Ajzen, 1991; Asare, 2015; López-Mosquera-Mosquera, 2016). 


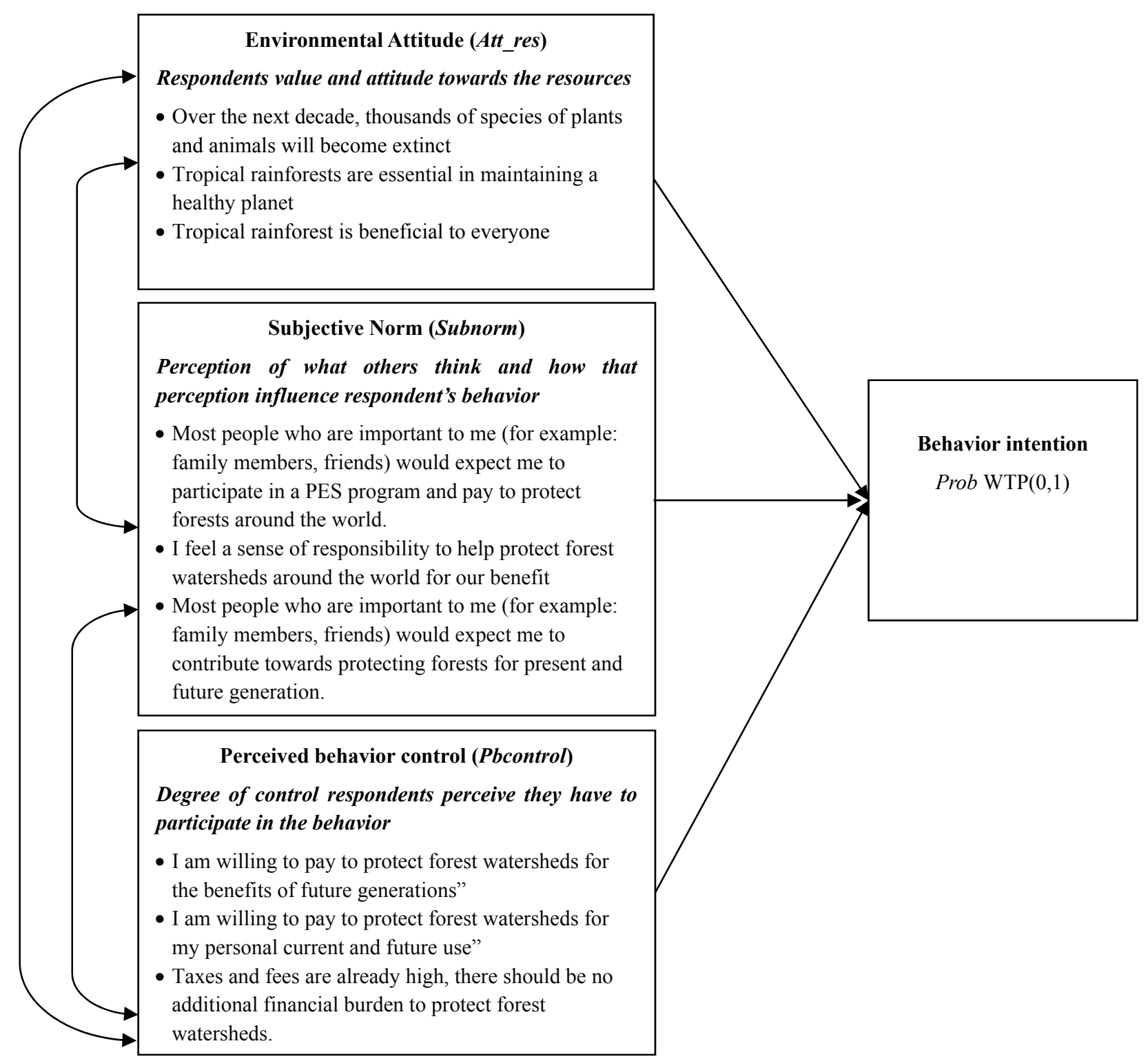

Figure 1. WTP as a behavioral intention explained by TPB constructs tailored for the establishment of payments to conserve tropical forest watersheds

In this study, we posit that an individual may derive utility from the restoration of imperiled tropical forest watershed conditions and the level of utility varies as a function of environmental attitudes (Att_res), subjective norms (Subnorm), and perceived behavioral controls (Pbcontrol), in addition to socio-demographic conditions, experience with the resource and affiliation with an environmental conservation group $(S)$. An individual's utility $\left(U_{i}\right)$ from particular outcomes is not observed but stated willingness to pay for particular scenarios are. Following a random utility framework (Hanemann 1984, 1989) an individual is willing to pay only if there is a positive change in utility associated with PES cost $\left(C_{\mathrm{PES}}\right)$ and corresponding improvement in watershed conditions $\left(q_{\mathrm{PES}}\right)$ over no intervention $(q 0)$ at no additional cost $\left(C_{0}\right)$.Hence, in a binary system where ' 1 ' captures a positive WTP, and ' 0 ' otherwise:

$$
W T P=\left\{\begin{array}{l}
1 \text { if } \Delta U_{i}>0 \\
0 \text { if } \Delta U_{i} \leq 0
\end{array} \quad i=1,2, \ldots, n\right.
$$

$\Delta U_{i}=\operatorname{Prob} \operatorname{WTP}(0,1)=f\left(\Delta C, \Delta q\right.$, Att_res $_{i}$, Subnorm $_{i}$, Pbcontrol $\left._{i} S_{i}\right)$, 


$$
\text { where } \Delta C=\mathrm{C}_{\mathrm{PES}}-\mathrm{C}_{0} \text {, and } \Delta q=\mathrm{q}_{\mathrm{PES}}-\mathrm{q}_{0} \text {. }
$$

Hence:

$$
\text { Prob WTP }(0,1)=f\left(\Delta C, \Delta q, \text { Att_res }_{i}, \text { Subnorm }_{i}, \text { Pbcontrol }_{i}, S_{i}\right) \text {, }
$$

And assuming the probability of WTP $(0,1)$ follows a linear function of predictors with a logistic link and random error, the coefficient for predictors for each explanatory variable can be estimated by maximum likelihood.

\section{Methods}

\subsection{Data Collection}

Data for our model were derived from a survey of US residents. Survey development followed Dillman, Smyth and Christian (2014) for developing and administering online surveys. A web-based online platform was the preferred choice for data collection due to time and cost effectiveness, reduced error and reported comparability with mail, face-to-face or phone-based surveys (Aguilar \& Cai, 2010; Buchanan \& Hvizdak, 2009; Dolnicar, Laesser \& Matus, 2009; Denscombe, 2006). In the first section of the survey, respondents were introduced to the concepts of ecosystem services PES programs, tropical forests and watersheds with relevant questions on the level of familiarity, perceptions and importance they attach to each of them. The second section focused on gauging TPB descriptors, attitudes toward a PES program as a tool to promote conservation of tropical rainforest watersheds, visitation experiences to tropical watershed forest ecosystems, and motivation for willingness to pay to protect forest ecosystem services. Attitudinal questions were preceded by descriptions and images portraying different ecosystem services as well as description of the concept of PES. The third section gathered stated WTP for a proposed hypothetical PES program to restore a degraded tropical rainforest watershed. To reduce potential response bias (Van Houtven et al., 2014), questions also included pictorial illustrations for better conceptualization. The final section collected respondents' socio-demographic information.

The WTP approach met characteristics for commonly used contingent valuation, hence guidelines offered by Mitchell and Carson (1989), Pascual et al. (2010) and Johnston et al. (2017) was followed. After careful pre-testing, we developed scenarios and chose a payment vehicle that met basic criteria for being realistic, credible, binding, and familiar to the sampled population (Johnston et al., 2017). We specified the conditions of the tropical rainforest to be restored as a 1000 square-mile degraded and poor functioning forested watershed, with the capacity to provide a bundle of key ecosystem services (improved water quality, improved landscape esthetic and improved habitat for essential tropical plant and animal species), but with functions expected to decline if no action is taken. The proposed hypothetical tropical rainforest PES program was located in Central America (Honduras) or West Africa (Ghana) to reflect the global contexts of tropical rainforest and add realistic and credible elements to the scenario. WTP cost levels (US\$ per household per year) were derived following initial pretesting with explorative open-ended format validated with past studies among US residents (Roesch-McNally \& Rabotyagov, 2016), and set at 30, 60, 90, 120 and 150. An increase in income tax imposed for a minimum of five years was selected as the payment vehicle after careful pre-testing and to minimize response bias by being credible, binding, familiarity and uniformity nationwide (Johnston et al., 2017).Alternative mechanisms such as an increase in utility bill costs would have been more suitable for goods where direct use values (e.g. water quality improvements) may be derived. Given the nature of the payment instrument, a protest question was included (Morrison, Blamey \& Bennet, 2000); it allowed assessing the potential of payment vehicle bias and ascertain how respondents will receive "income tax" as a payment tool in the final questionnaire.

WTP can be elicited in various ways with the most common being the dichotomous choice referenda approach where respondents simply indicate whether they would vote "yes" or "no" at a single, specific (but varying across respondents) dollar amount (Arrow et al., 1993) and the payment card approach (Cameron \& Huppert 1989). However, several authors have overtime raised concerns about these approaches. For example, Loomis and Ekstrand (1999) posit that both of these approaches assume the respondent has no uncertainty regarding their stated preferences and in the case of the "yes" and "no" to the single specific dollar amount approach, the researcher only determines whether the respondents WTP is greater or less than the individual's bid thus rendering it statistically inefficient. According to Loomis and Ekstrand (1999), it is appropriate to consider respondents preference certainty when dealing with passive use values, in this instance option, indirect and non-use values in view of the fact that, respondents may have not thought about the economic trade-offs they would make for conservation of tropical rainforest as they may have for in country use values for forest recreation or private good consumption decisions. Thus, restricting respondents to answer "yes" or "no" may result in respondents who are uncertain about their WTP preferences to state "yes" to register support for the 
environmental program when they would actually vote "no" (Brown, Champ, Bishop \& McCollum,1996; Champ, Bishop, Brown \& McCollum, 1994). Hence following Welsh and Bishop (1992), Ready, Whitehead and Bloomquist (1995) and Loomis and Ekstrand (1999), WTP preferences in this study was first elicited using a multiple-bounded approach to a range of the specified dollar values as a way to incorporate respondents' level of certainty. This approach although similar to the payment card allows respondents to sequentially indicate their WTP on an ordinal scale $(1=$ Definitely not pay this amount, $2=$ Probably not pay this amount, $3=$ Unsure, $4=$ Probably/Very likely pay this amount, $5=$ Definitely pay this amount) to the specified range of dollar amounts (Loomis \& Ekstrand, 1999). Figure 2 illustrates the basic design of the CV scenario presented to respondents that incorporated pictorial descriptions besides prior information and pictures on tropical forest and PES description. The choice of the hypothetical tropical watershed located in Central America (Honduras) or West Africa (Ghana) was to reflect the global contexts of forest conservation initiatives as well as to capture ecosystems that denote the likelihood of deriving potential option use values, indirect or non-use values.

The bracket of a respondent's WTP from the multiple bound method presume a person who checks $\$ 30.00$ but unsure at $\$ 90.00$ is interpreted as being willing to pay $\$ 30$ but not $\$ 90.00$. The respondent's WTP thus lies within the interval between $\$ 30.00$ and $\$ 90.00$. According to Loomis and Ekstrand (1999) and Poe and Welsh (1995), there is some statistical distribution function of a respondent's WTP within this interval. Hence generalizing this to the sample of respondents that switch between" Probably not pay this amount" at the lower dollar amount, $\$ C i_{P E S \_l o w e r}$, and unsure at the higher dollar amount, $\$_{C I P E S_{-} \text {Higher, }}$ the log-likelihood function is given as:

$$
\ln (\mathrm{L})=\sum_{i=1}^{n} \ln \left\{F\left(\$ C i P E S_{-} \text {Higher } ; \beta\right)-F\left(\$ C i P E S_{-} \text {Lower } ; \beta\right)\right\},
$$

where $\beta$ is the parameter vector to be estimated using a particular distribution function. We addopted a logistic distribution function to maximize equation 4 using the TPB predictors as described in equation 1 to 3 (Welsh \& Bishop 1993). Ordinal WTP responses were therefore recoded to ' 1 ' when respondents chose either "definitely willing to pay this amount" or "very likely pay this amount" and ' 0 ' when choice was "unsure, "probably not pay this amount" or "definitely not pay this amount" in conformity with referendum literature (Loomis \&Ekstrand, 1997; Polasky, Gainutdinova \& Kerkvliet, 1996). WTP elicitation questions were preceded by a cheap talk script to remind respondents about the financial implications of their answers (Blumeschein, Blomquist, Johannesson, Horn \& Freeman, 2008; Ninan, 2014; Vásquez-Lavín, Ibarnegaray, Ponce Oliva, \& Hernández Hernández, 2016). 


\section{TROPICAL RAINFOREST PES}

Think about this scenario: A payment for ecosystem services (PES) program is being proposed to either restore and manage a degraded tropical rainforest watershed through improved vegetation and landscape management in Ghana (Africa) or Honduras (Central America). The current degraded conditions provide limited ecosystem services and benefits are likely to decline if no action is taken.

In the next set of questions, we would like to know your willingness to pay to restore the degraded tropical rainforest watersheds in Africa or Central America.

Remember the scenario: financial contributions to a PES Watershed Program would go to support the restoration and management of a 1,000 square-mile degraded tropical rainforest watershed in Africa or Central America, although you have no intention of ever visiting these places.

Paying to restore the degraded tropical rainforest watershed will offer the following key benefits: increase in water quality by reducing excess nutrient contamination and other sources of pollution,

improved habitat for increased threatened native plant and animal species, and increased watershed landscape beauty within that country.

This program will cost your household anywhere from \$30-\$150 through an annual increase in income tax for five years.

Would you be willing to pay the specified amount to restore the tropical rainforest watershed described above?

\begin{tabular}{|c|c|c|c|c|c|}
\hline $\begin{array}{l}\text { Cost to } \\
\text { you per } \\
\text { Year }(\$)\end{array}$ & $\begin{array}{l}\text { Definitely } \\
\text { not pay this } \\
\text { amount }\end{array}$ & $\begin{array}{l}\text { Probably } \\
\text { not pay } \\
\text { this } \\
\text { amount }\end{array}$ & Unsure & $\begin{array}{l}\text { Probably/Very } \\
\text { likely pay this } \\
\text { amount, }\end{array}$ & $\begin{array}{l}\text { Definitely } \\
\text { pay this } \\
\text { amount }\end{array}$ \\
\hline 30 & {$\left[\begin{array}{ll} & ]\end{array}\right.$} & {$\left[\begin{array}{ll} & \end{array}\right]$} & {[} & {$\left[\begin{array}{l}\text { ] } \\
\text { ] }\end{array}\right.$} & {[} \\
\hline 60 & {$\left[\begin{array}{l}\text { ] } \\
\text { ] }\end{array}\right.$} & {$\left[\begin{array}{ll} & \end{array}\right]$} & {[} & {$\left[\begin{array}{ll} & ]\end{array}\right]$} & {$\left[\begin{array}{ll} & ]\end{array}\right]$} \\
\hline 90 & {$\left[\begin{array}{ll} & ]\end{array}\right.$} & {$\left[\begin{array}{ll} & \end{array}\right]$} & {[} & {$\left[\begin{array}{l}\text { ] } \\
\text { ] }\end{array}\right.$} & {[} \\
\hline 120 & {$\left[\begin{array}{ll} & ]\end{array}\right]$} & {$\left[\begin{array}{ll} & ]\end{array}\right]$} & ] & {$\left[\begin{array}{ll} & ]\end{array}\right]$} & {$\left[\begin{array}{ll} & ]\end{array}\right]$} \\
\hline 150 & {$\left[\begin{array}{ll} & ]\end{array}\right.$} & {$\left[\begin{array}{ll} & ]\end{array}\right.$} & {[} & {$\left[\begin{array}{ll} & ]\end{array}\right.$} & {$\left[\begin{array}{ll} & ]\end{array}\right.$} \\
\hline
\end{tabular}

Figure 2. Example of one WTP scenario for the restoration of tropical rainforest watershed. NB: Scenarios showed one price level at a time and were sequentially adjusted to include different price levels of annual increments in income taxes

Data collection was conducted in the month of April 2016. Only one complete survey per participant was allowed and data collection was stopped once the target number of complete responses was achieved. All data collection protocols were approved by the (name institution to be inserted after the review process) Institutional Review Board.

\subsection{Data Analysis}

Data were analyzed for descriptors of centrality and dispersion. Prior to estimation of the logistic regression we created index variables for TPB indicators. The mean score of index variables forAtt_res, Subnorm, Pbcontrolwere constructed by aggregating statements under each of these indicators into one variable based on Cronbach alpha reliability test on responses to the statements. Statements which were found to connote a negative undertone were reverse coded to ensure consistency with remaining positive statement and easier interpretation. Three different regression models were estimated. The first was a reduced model that controlled for the effects of cost, and TPB 
variables. The second model was expanded to include socio-demographic factors and direct experience with tropical rainforest watershed, and the third model also controlled for interaction effect of gender and the TPB components following López-Mosquera (2016) gender differentiation with TPB predictors. Goodness-of-fit of all models was assessed using the Akaike Information Criterion (AIC) and Bayesian Information Criterion (BIC). Explanatory variables were tested for correlation and multicollinearity prior to model estimation. Table 1 shows variable descriptions, Cronbach alpha $(\alpha)$ gauging the internal consistency of responses to statements used under each of the TPB predictors and associated descriptive statistics. Appendices A and B show correlation among variables used in the model analysis and the variance inflation factor index as an indicator of multicollinearity, respectively.

The mean WTP as a measure of economic values for the improvement in tropical rainforest watershed was estimated using the "grand constant" formulae (Giraud, Loomis \& Johnson, 1999; Hanemann, 1989; Hu, Batte, Woods, \& Ernst, 2011; Revelt\& Train, 1998):

$$
\text { Mean } W T P=-\frac{1}{\beta c}(G),(5)
$$

where $\beta c$ is the estimated coefficient of cost and $G$ is a grand constant computed as the sum of the estimated coefficients (excluding the cost variable) multiplied by their respective variable mean and divided by the coefficient of the cost variable. Stata version 12.0 was used to perform all data analyses.

\subsection{Study Limitations}

Generally, economic valuations based on contingent scenarios are bedeviled with several limitations (Hausman 2012; Haab, Interis, Petrolia \& Whitehead, 2013). For example, respondents in CV studies do not always value goods as they are described but rather how the issue is constructed within their personal worldview. Two limitations can be outlined: first, validity based on information effect due to the potential existence of asymmetric information across individuals with respect to conceptualization of the resource in question i.e. tropical rainforest. A detailed pictorial and descriptive overview of the concept of use (PES and tropical degraded watersheds) was provided prior to elicitation of WTP. Such holistic information in a survey according to Venkatachalam (2000) is capable of reducing biases due to information effect. The second limitation is the use of annual increase in income tax which is capable of introducing potential response bias. As reiterated in the previous section, the payment vehicle used in the final survey was selected based on preference of majority of respondents in an initial open-ended pre-testing of the survey. Nevertheless, our estimates may likely be subjected to response bias probably due to issues of social appeal leading to free ridership behavior. The results of this study are thus presented within the caveats outlined above.

Table 1.Descriptions of variables used in WTP model

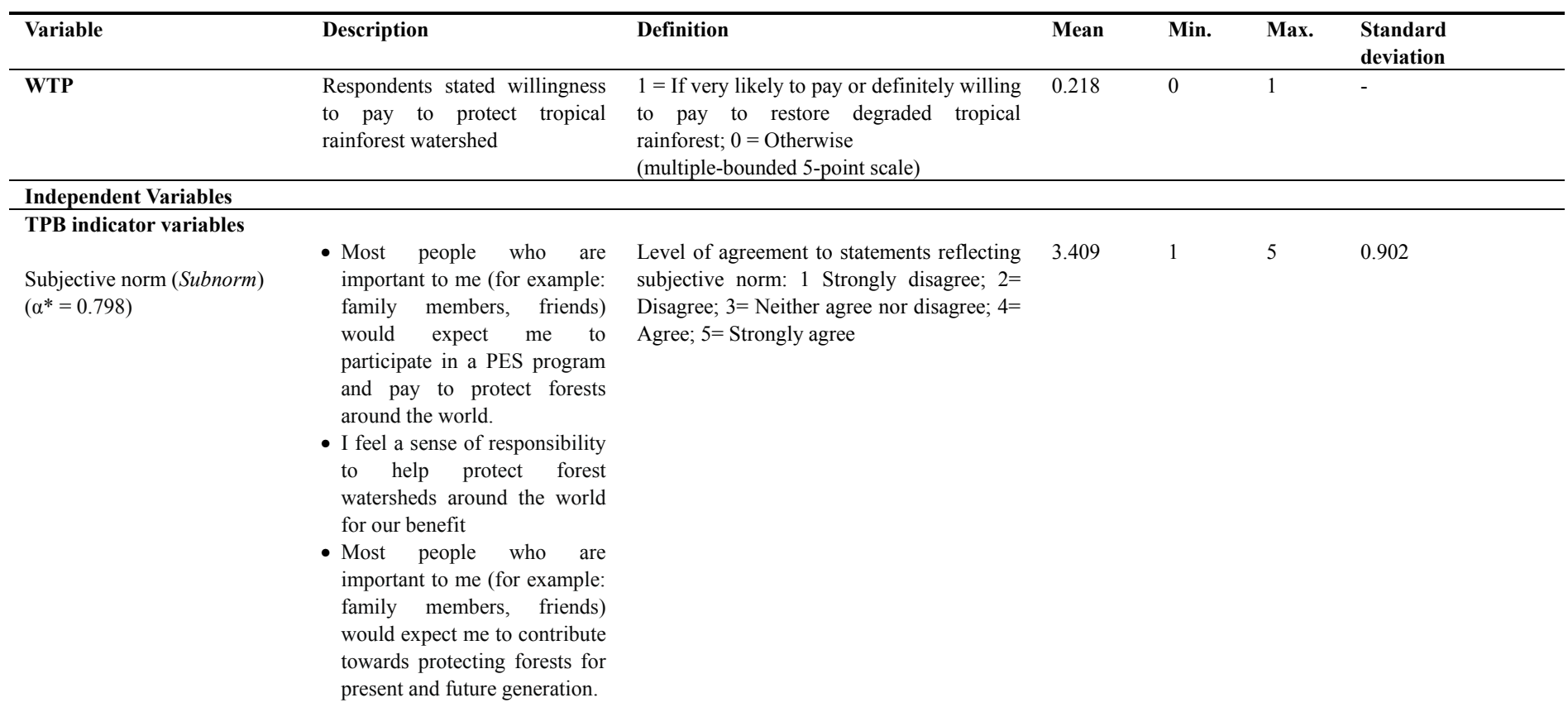


Perceived behavior control - I am willing to pay to protect (Pbcontrol) $\left(\alpha^{*}=0.763\right)$

forest watersheds for the benefits of future generations"
- I am willing to pay to protect forest watersheds for my personal current and future use"

- "Taxes and fees are already high, there should be no additional financial burden to protect forest watersheds.

Environmental attitudes - Over the next decade, towards forests and tropical thousands of species of plants rainforest (Att res) $\left(\alpha^{*}=0.767\right)$ and animals will become extinct
Level of agreement to statements reflecting Perceived behavior control: 1 Strongly disagree; $2=$ Disagree; $3=$ Neither agree nor disagree; $4=$ Agree; $5=$ Strongly agree
Level of agreement to statements reflecting positive attitudes towards tropical rainforest: 1 Strongly disagree; $2=$ Disagree; $3=$ Neither agree nor disagree; $4=$ Agree $;=$ Strongly agree
5

0.887

- Tropical rainforests are essential in maintaining a healthy planet

- Tropical rainforest is beneficial to everyone

Cost of Tropical PES program Cost

Cost of tropical rainforest PES program per household per year

Socio-demographic, experience and support for conservation

Gender (Female)

Gender of respondents

Age (Age) :

Age of respondents

College education $(E d u c)$

Education of respondents

Visit experience (Experience)

Respondents reported visit experience to a tropical rainforest outside the US.

Support for environmental Financial contribution and or group

affiliation with an environmental conservation group or forestry organizations clubs or society (e.g. Audubon society, Sierra Club, WWF).

Interaction between TPB indicators and Gender

Female_Subnorm

Interaction between Subjective norm and female respondents

Female_Pbcontrol Interaction between perceived behavior control and female respondents

Female_Attres
Annual cost per household $=\$ 30, \$ 60, \$ 90$, $\$ 120, \$ 150$.

$1=$ Female; Male $=0$

$1=\mathrm{Up}$ to 54 years; $0=$ greater than 54 years

$1=$ Respondent with at least a college education; 0 if otherwise

$1=$ Have visited tropical forested watershed; $\quad 0.225$

0 if otherwise

$1=$ Provide financial support and/or affiliated with environmental conservation group; 0 if otherwise $\begin{array}{llll}4.132 & 1 & 5 & 0.718\end{array}$

$\begin{array}{llll}90 & 30 & 150 & 42.431\end{array}$

$\begin{array}{llll}0.521 & 0 & 1 & -\end{array}$

$0.488-0$

$0.225 \quad 0$

$\begin{array}{llll}1.737 & 0 & 5 & 1.779 \\ 1.664 & 0 & 5 & 1.722 \\ 2.170 & 0 & 5 & 2.141\end{array}$

$0.171 \quad 0 \quad 1$

$\begin{array}{lllll}\text { Female x Attitude towards resource } & 2.170 & 0 & 5 & 2.141\end{array}$
Interaction between attitude towards the resource and female respondents

$\$$ Age category followed Aguilar, Cai and Butler (2017) when examining positive attitudes among US residents towards forest management.

* Cronbach alpha $(\alpha)$ measures the internal consistency and reliability of responses to statements being used to measure respective latent variables. Cronbach's alpha coefficient: $>0.7=$ acceptable internal consistency and reliability among items (Cronbach \& Shavelson, 2004).

"The statement "Taxes and fees are already high, there should be no additional financial burden to protect forest watersheds" was reverse coded to maintain the consistency with the other two positive statement used in measuring perceived behavior control.

\section{Results}

A total of 1002 complete surveys were obtained from 1200 participants. The sample was deemed representative of the US population of individuals 18 and older after comparing demographic information with data from the most recent US Census (US Census Bureau, 2015).

\subsection{Familiarity with Tropical Rainforest Watersheds, and PES Perceptions}

In our sample $55.49 \%$ of respondents indicated familiarity with tropical rainforests. The statement on perceptions about paying to protect tropical rainforest, "My household should pay landowners to restore 
degraded tropical rainforest watersheds outside the U.S. (Example: Africa or Central America)" received mixed opinions. Figure 3 shows reported level of agreement to this statement self-recorded on a 5-point Likert scale.

| Close to $40 \%$ of respondents reported either-strong disagreement $(18.2 \%)$ and disagreement $(21.1 \%)$ to the statement, whereas $34.2 \%$ neither disagreed or agreed. However, approximately $26.5 \%$ of respondents agreed $(18.26 \%)$ or strongly agreed $(8.28 \%)$ to the statement reflecting the need to support the protection of tropical rainforest watershed through financial compensation. The mean derived from the 5-point Likert scale for this statement was 2.77 denoting level of agreement greater than 2 (Disagree).

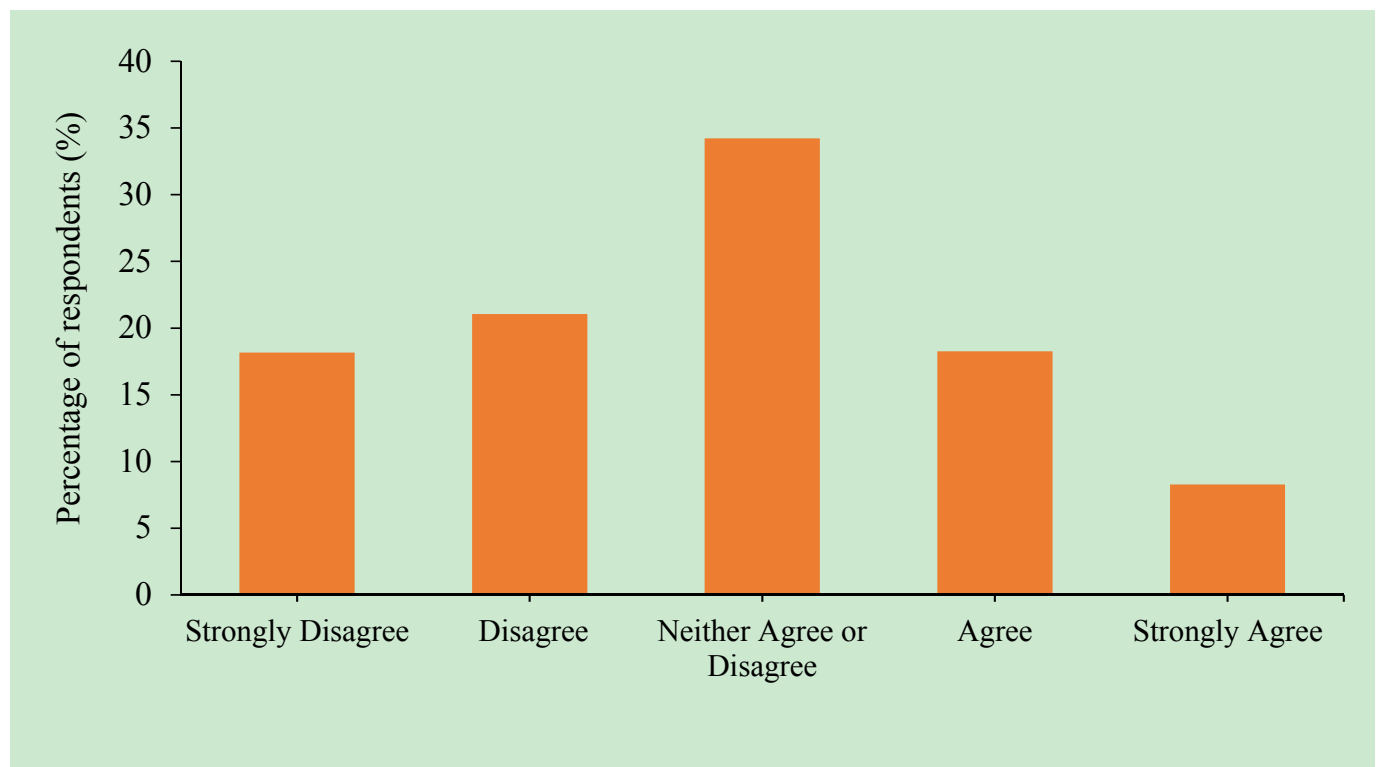

Figure 3. Respondents' level of agreement with statement on paying landowners to restore degraded tropical rainforest (assessed on a 5-point Likert scale)

\subsection{TPB Descriptors}

Respondents reported mixed opinions on the statements denoting TPB predictors. Regarding statements reflecting subjective norms (Subnorm), 35.6\% and 58.3\% of respondents agreed or strongly agreed to the statements "Most people who are important to me (for example: family members, friends) would expect me to participate in a PES program and pay to protect forests around the world" and "I feel a sense of responsibility to help protect forest watersheds around the world for our benefit" respectively. Also, $40.8 \%$ and $27.4 \%$ of respondent neither agreed nor disagreed with both statements respectively. About $56.2 \%$ of respondents agreed or strongly agreed to the third statement "Most people who are important to me (for example: family members, friends) would expect me to contribute towards protecting forests for present and future generation. The mean derived from the 5-point Likert scale for subjective norm was 3.41 denoting level of agreement greater than 3 (Neither agree nor disagree). Agreement to statements reflecting perceived behavior control (Pbcontrol) showed similar trend. Approximately $58.7 \%$ agreed or strongly agreed to the statement "I am willing to pay to protect forest watersheds for the benefits of future generations". About $56.2 \%$ and $20.5 \%$ agreed or strongly agreed to the statements "I am willing to pay to protect forest watersheds for my personal current and future use" and "Taxes and fees are already high, there should be no additional financial burden to protect forest watersheds" respectively. The aggregated mean for the variable perceived behavior control was 3.23 also denoting agreement greater than neither agree nor disagree. The aggregated mean for the statements reflecting attitude towards the resource (Att_res) was 4.13. Level of agreements to all three statements were relatively higher. Approximately $65.7 \%, 85.2 \%$ and $82.3 \%$ of respondents agreed or strongly agreed to the statements "Over the next decade, thousands of species of plants and animals will become extinct", "Tropical rainforests are essential in maintaining a healthy planet" and "Tropical rainforest is beneficial to everyone". Only 9.4\%, 1.7\% and 3.9\% disagreed or strongly disagreed with the first, second and third statements reflecting attitude towards the resource.

\subsection{WTP to Restore Degraded Tropical Rainforest Watershed}

Descriptively, approximately $40 \%$ of respondents were willing to pay at the cost of US $\$ 30.00$. At the mean cost of US $\$ 90.00$, only $17.2 \%$ expressed their willingness to pay. This decreased to about $12 \%$ when the cost is at the 
maximum value of US\$150.00. Hence, the WTP responses did not exhibit the "fat tail" phenomena, a common occurrence in most CV studies. A "fat tail" problem indicates an understatement of the highest cost level amount (Haab and McConnell, 2002; Amponin et al., 2007), allowing a majority of respondents to opt for a positive response. Overall, $21.82 \%$ of respondents were willing to make an annual monetary contribution ranging from US\$ 30.00 to US\$ 150.00 through an annual increase in income tax for five years. Results of the logistic regression models predicting WTP are presented in Table 2 including coefficients, standard errors, Type-I error significance, and odds ratios. Model 1 show, the expected inverse and statistically significant effect of higher PES program cost to a household on WTP. With the TPB predictors, only subjective norm showed a positive and statistically significant effect on WTP.

Model 2 that also controlled for socio-demographic variables and experience had a better goodness-of-fit and showed consistency in the directions of coefficients of TPB descriptors from model 1 except for Pbcontrol. Also, all the explanatory variables were statistically significant (Type-I error $<0.05$ ) except for attitude towards forests in general and tropical rainforest (Att_res). It is noticeable that once socio-demographic information, experience and environmental support were controlled for, Pbcontrol turned positive and exhibited a statistically significant effect (Type-I error $<0.1$ ). The strong statistical significance and direction of Subnormin model 1 remained unchanged but with a relatively lower magnitude of odds ratio. Model 2 also shows how subjective norm was a very strong predictor of WTP with odds ratio of 3.5. The second strong predictor of WTP was support for environmental groups with an odds ratio of 2.5. Model 2 shows that, on average, individuals who have visited a forested watershed in a tropical country, had attained a college degree education, and support an environmental group were more likely to be willing to pay for the proposed PES program to restore degraded tropical rainforest watersheds. Female respondents and respondents younger than 55 years were noted to be less likely to be willing to pay. A third model specification was necessitated to understand the gender effect on the TPB predictors.

Model 3 and Model 2 revealed comparatively similar model parameters (model fitness) denoted by higher Pseudo $\mathrm{R}^{2}$ of 0.286 and 0.287 respectively. Model 3 had a marginally lower AIC value when gender was interacted with TPB indicators. Coefficients show several noteworthy changes in comparison to the previous reduced model (Model 2). Controlling for the interaction effect of gender with TPB indicators rendered the marginally significant perceived behavior control (Pbcontrol) to be insignificant. The two most dominant predictor of WTP remained unchanged with subjective norm and support for environmental groups maintaining their direction and strong statistical significance. On average, respondents who provide financial support and/or affiliated with an environmental conservation units or groups are 2.5 times more likely to be willing to pay than those who otherwise do not support any environmental conservation group, ceteris paribus. The direction of female gender on WTP changed direction to a direct effect (positive) but was statistically insignificant. Only the interaction variable of female and subjective norm showed a statistical significance (Type-I error $<0.05$ ) among the three interacted gender and TPB variables. Females who perceived the social pressure i.e. what others think of their environmental attitudes towards contributing to protect tropical forest and forests in general would be $32.7 \%$ less likely to be willing to pay for the tropical PES program relative to men with the similar perceived social pressure, ceteris paribus. 
Table 2. Parameter estimates from logit models of WTP to restore degraded tropical rainforest watershed for improved ecosystem services $(n=1,002)$

\begin{tabular}{|c|c|c|c|c|c|c|c|c|c|}
\hline \multirow[t]{2}{*}{ Variables } & \multicolumn{3}{|c|}{$\begin{array}{c}\text { Model } 1 \\
\text { TPB }\end{array}$} & \multicolumn{3}{|c|}{$\begin{array}{c}\text { Model 2 } \\
\text { TPB } \\
+ \text { Socio-demographic } \\
+ \text { experience }+ \text { support for } \\
\text { conservation }\end{array}$} & \multicolumn{3}{|c|}{$\begin{array}{c}\text { Model 3 } \\
\text { TPB } \\
+ \text { Socio-demographic } \\
+ \text { experience + support for } \\
\text { conservation } \\
\text { + interaction variables }\end{array}$} \\
\hline & Coeff. & $\begin{array}{l}\text { Std. } \\
\text { Errors }\end{array}$ & $\begin{array}{l}\text { Odds } \\
\text { ratios }\end{array}$ & Coeff. & $\begin{array}{l}\text { Std. } \\
\text { Errors }\end{array}$ & $\begin{array}{l}\text { Odds } \\
\text { ratios }\end{array}$ & Coeff. & $\begin{array}{l}\text { Std. } \\
\text { Errors }\end{array}$ & $\begin{array}{l}\text { Odds } \\
\text { ratios }\end{array}$ \\
\hline Cost & $-0.018 * * *$ & 0.001 & 0.982 & $-0.020 * * *$ & 0.001 & 0.980 & $-0.020 * * *$ & 0.001 & 0.980 \\
\hline Subnorm & $1.609 * * *$ & 0.081 & 4.999 & $1.254 * * *$ & 0.085 & 3.503 & $1.434 * * *$ & 0.114 & 4.195 \\
\hline Att_res & 0.015 & 0.070 & 1.016 & 0.078 & 0.072 & 1.081 & 0.093 & 0.101 & 1.098 \\
\hline Pbcontrol & -0.062 & 0.075 & 0.940 & $0.130^{*}$ & 0.079 & 1.139 & 0.050 & 0.109 & 1.051 \\
\hline Female & & & & $-0.177 * *$ & 0.085 & 0.838 & 0.752 & 0.650 & 2.121 \\
\hline Age & & & & $-0.947 * * *$ & 0.134 & 0.388 & $-0.926 * * *$ & 0.134 & 0.396 \\
\hline $\begin{array}{l}\text { College } \\
\text { education }\end{array}$ & & & & $0.318^{* * *}$ & 0.085 & 1.374 & $0.327 * * *$ & 0.086 & 1.386 \\
\hline $\begin{array}{l}\text { Visit } \\
\text { experience }\end{array}$ & & & & $0.506^{* * *}$ & 0.095 & 1.658 & $0.498 * * *$ & 0.096 & 1.645 \\
\hline $\begin{array}{l}\text { Support_ENV } \\
\text { group }\end{array}$ & & & & $0.910 * * *$ & 0.099 & 2.484 & $0.913 * * *$ & 0.099 & 2.493 \\
\hline $\begin{array}{ll}\text { Female } & x \\
\text { Subnorm } & \end{array}$ & & & & & & & $-0.396^{* *}$ & 0.165 & 0.673 \\
\hline $\begin{array}{l}\text { Female } \\
\text { Attres }\end{array}$ & & & & & & & -0.028 & 0.144 & 0.972 \\
\hline $\begin{array}{l}\text { Female } \quad x \\
\text { Pbcontrol }\end{array}$ & & & & & & & 0.199 & 0.157 & 1.220 \\
\hline Constant & $-5.527 * * *$ & 0.312 & 0.004 & $-5.337 * * *$ & 0.326 & 0.005 & $-5.820 * * *$ & 0.473 & 0.003 \\
\hline Log likelihood & -1999.169 & & & -1877.688 & & & -1874.4108 & & \\
\hline Pseudo $\mathrm{R}^{2}$ & 0.239 & & & 0.286 & & & 0.287 & & \\
\hline $\mathrm{LR} \mathrm{Chi}^{2}(4)$ & 1257.89 & & & $\operatorname{LRChi}^{2}(9)$ & 1500.85 & & $\operatorname{LR~Chi}^{2}(12$ & 1507.41 & \\
\hline Prob $>$ Chi2 & 0.001 & & & 0.001 & & & 0.001 & & \\
\hline AIC & 4008.339 & & & 3775.376 & & & 3774.822 & & \\
\hline BIC & 4040.935 & & & 3840.568 & & & 3859.571 & & \\
\hline
\end{tabular}

Statistically significant marginal effect at $10 \%(*), 5 \%(* *)$, and $1 \%(* * *)$ Type-I error

\subsection{Estimated Economic Values for Tropical Rainforest Watersheds}

The economic values (mean WTP and respective confidence intervals)(Table 3) were estimated from Model 3 which controlled for all variables including interaction terms. The mean WTP provides information on the economic values associated with each latent variable of the TPB in paying to restore a degraded tropical rainforest watershed in e.g. Central America or Africa. The key bundled ecosystem services of focus were improved clean water services, improved habitat for plant and animal species and improved vegetative aesthetic landscape. Monetary estimates ranged between US\$ 2.50 and US\$ 146.32 per household per year. The mean WTP estimate considering the entire sample was computed as US\$ 146.32 per household per year. Implicitly, a respondent on average would be willing to pay approximately US\$ 146 per household per year to restore a 
degraded tropical rainforest watershed. The amount is above the mean preset program cost of US\$ 90.00 . The estimated mean economic values for subjective norm remained higher than the preset minimum cost of US\$ 30.00. The estimated economic value associated with attitude towards the resources and perceived behavior control were comparatively very low. Generally, this suggests that having a positive attitude about tropical rainforest as well as a reflection of ability to make contribution (e.g. budget constraints) towards protecting tropical rainforest did not necessarily translate into higher economic values from improved tropical rainforest watershed conditions. Rather, subjective norms were of greater importance to WTP.

Table 3. Mean WTP for tropical rainforest watershed

\begin{tabular}{llll}
\hline & $\begin{array}{l}\text { Mean } \\
\text { estimates }\end{array}$ & WTP & 95\% confidence intervals \\
\cline { 2 - 4 } & \multicolumn{2}{l}{ (US\$ per household per year) } \\
\hline Subjective Norm & 71.97 & 59.35 & 84.59 \\
Perceived Behavior & 2.50 & $(-) 8.23$ & 13.23 \\
Attitudes & 4.68 & $(-) 5.29$ & 14.65 \\
Whole Sample & 146.32 & 84.68 & 207.95 \\
\hline
\end{tabular}

$\$ 95 \%$ confidence intervals computed using parametric bootstrapping.

\section{Discussion}

The results of this study suggest that a section of the U.S. public is willing to make monetary contributions to restore ecological functions of tropical rainforest watersheds. Overall, the mean annual WTP amounts to US\$ 146 per household per year. This amount reflects economic values for tropical rainforest watersheds that would largely be rooted in option and non-use value motivations given the distance between our sampled payers and the locality of the ecosystem in question. Our results seem to be within past ranges such as those reported by Roesch-McNally and Rabotyagov (2016) that ranged from US\$ 115 to 206 per household per year in voluntary payments for improved forest ecosystem services in Oregon, US, however of a local content. A median WTP of US\$ 114.72 per household per year was obtained for protection of watersheds in Flagstaff, Arizona (Mueller, 2014). Our findings complement past studies that have focused on locally-occurring benefits and highlights opportunities for PES programs with transboundary benefits namely option and non-use values (e.g. bequest, existence).

Specific to geographically distant beneficiaries' willingness to pay for tropical rainforest conservation, the only comparable study to our knowledge is that of Kramer and Mercer (1997) who estimated U.S. residents' WTP to protect tropical rainforest with an average one-time payment of US\$ 31-46(after adjusting for inflation) per household to protect additional $5 \%$ of tropical forests. Although considerably smaller than our more recent estimates, differences might be likely due to greater public awareness for environmental problems and global processes, higher accessibility to environmental information through different communication platforms, greater incomes, among others (Pew Research Center, 2017). Rising household income in particular has been associated with increased WTP for forest conservation initiatives (Vincent et al., 2014). A key finding of this study is that approximately $40 \%$ of respondents were willing to pay to restore a degraded foreign tropical rainforest at the preset minimum annual cost of US $\$ 30.00$ per household. Nonetheless, given the stated preference nature of this study we cannot rule out that responses may have been influenced by social desirability, avoidable consequences and free ridership issues, among others (Johnston et al., 2017; Leggett, Kleckner, Boyle, Dufield \& Mitchell, 2003; Obeng \& Aguilar, 2018).

Our full model integrating TPB descriptors, socio-demographic information and specific gender effects had somewhat a greater statistical power. Our Models further show that TPB offers a strong framework to intention to pay to restore degraded ecosystems even if direct benefits might not occur. This study also shows that the TPB framework should be enriched to capture other sources of variance when modeling environmental behaviors (Han \& Hensen, 2012;Liebe, Preisendörfer \& Meyerhoff, 2011; López-Mosquera-Masquerez, 2016; Thorgersen\& Olander, 2006). Within the context of this study, it is evident that the inclusion of socio-demographic, experiential and past behavioral conditions improved the predictability of WTP as denoted by AIC and BIC indices (Model 1 and 2). 
Among TPB indicators, subjective norm was consistently the stronger predictor of WTP. This affirms what pertains in the literature (e.g., Bishop \& Barber 2015; Botetzagias, Dima \&Malesios, 2015; Pouta \& Rekola, 2001) with regards to WTP and observed behavior, suggesting the likely influence of peers on environmentally-desirable and social preferable behavior. We posit that this is also the case once the model controlled for other variables that might better capture attitudes underlying actual behaviors by individuals. Perceived behavior control had a relatively weak absolute and statistical effect on WTP and was only noted in model 2 and not consistent across all three models. Nevertheless, our finding is consistent with Pouta and Rekola (2001) that predicted WTP for abatement of forest regeneration in Finland using the TPB. Contrary to our findings, Botetzagias et al., (2015) found perceived behavior control to be rather the most important consistently predictor of a pro-environmental behavior as was the case of recycle intention among Greek citizens. The third TPB predictor of environmental attitude did not have a significant impact on WTP.

An increase in the annual cost of the proposed PES program had an inverse effect on the probability of positive WTP outcomes. Else constant, the marginal effect of a US $\$ 1$ annual increase in the proposed PES program costs through higher income taxes per household was a $2 \%$ reduction in WTP at the base category which was statistically significant at the 1\% Type-I error level. Although our sample was sensitive to higher PES program costs, there is a non-negligible share of individuals willing to support it although throughout all cost levels for the hypothetical PES program there were more negative than positive WTP responses (Figure 4).

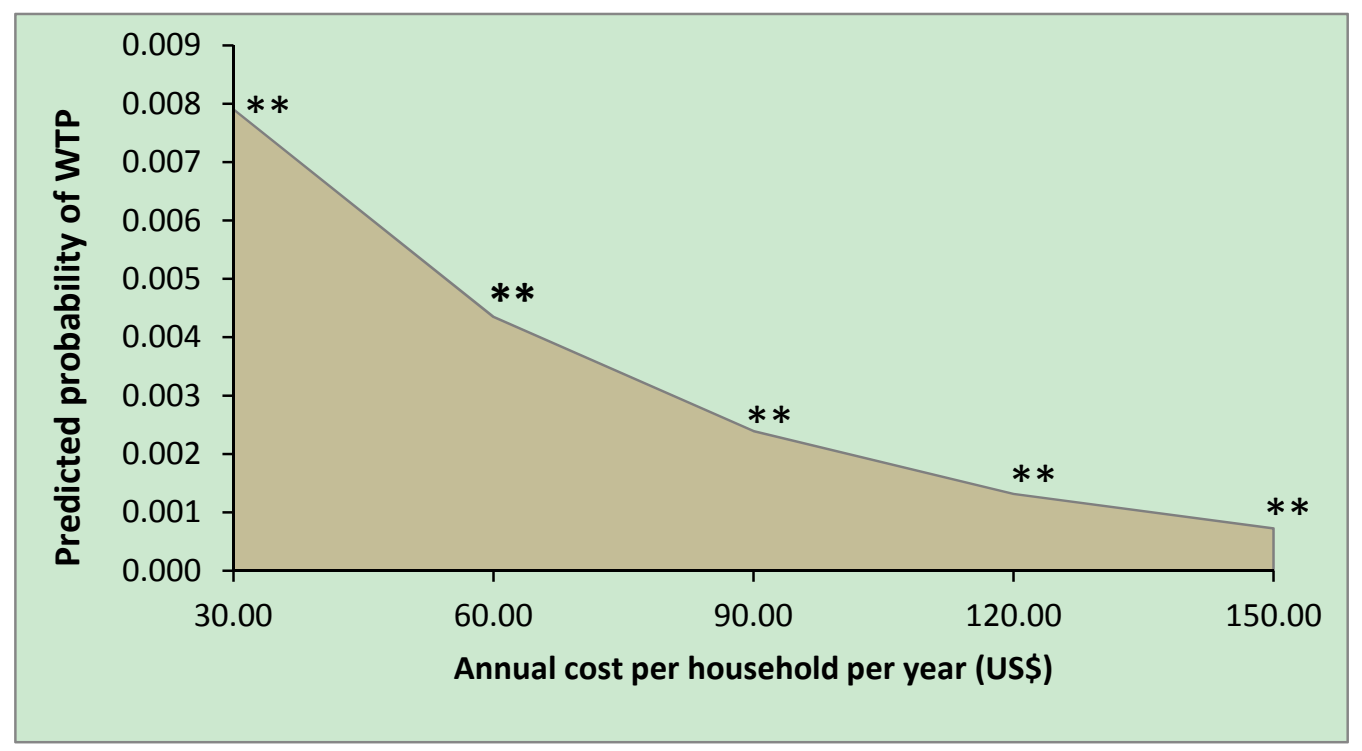

Figure 4. Marginal probability effects on WTP to restore a degraded tropical rainforest watershed for bundled ecosystem services provision through PES at different cost per household per year. All effects were statistically significant at 5\% Type-I error level

\section{Conclusions}

The TPB has shown from this study to be more informative, realistic and flexible analytical framework for determining distant co-beneficiaries WTP to support tropical rainforest conservation. There is evidence that individuals in the US place value in the restoration and conservation of an ecosystem from which there might only be indirect, option or non-uses. As denoted by stated WTP for the restoration of a degraded tropical rainforest watershed, there is a non-negligible segment of the US population willing to financially support such initiatives particularly based on subjective norms. On average, $21.82 \%$ of respondents were willing to make an annual monetary contribution ranging from US\$ 30.00 to US\$ 150.00 through an annual increase in income tax. The estimated economic value from restoring tropical rainforest watershed amounted to US\$146.32 per household per year.

Subjective norms and respondents past support for an environmental organization group were found to be strong predictors of WTP to restore a degraded tropical rainforest watershed; individuals engaged in supporting environmental groups were 2.5 times more likely to agree to the proposed PES program. Perceived behavior control had a relatively weak significant effect on WTP while attitude towards the resource had no significant impact. Female respondents, else constant, were over $16.2 \%$ times less likely than males to support such PES 
program (Model 2) and 32.7\% less likely to do so in the face of self-reported level of social pressure expressed in subjective norm for performing this particular behavior. Individuals with at least a college education were more likely to agree to participate in the proposed PES program. However, relatively younger age group were less likely to willing to pay to protect tropical rainforest through the proposed program. Those who have had an experience visiting forests abroad were 1.7 times more likely to agree to the proposed program than those who had not. Generally, most PES programs are limited by scope of funding in particular tropical countries. Budgets are often secured for a limited time, but knowing that individuals would be willing to pay for programs geared towards protecting tropical rainforest watershed ecosystems based on non-use, option and indirect values provides a useful reference point for efficient PES decision-making.

\section{Acknowledgements}

This research was made possible thanks to the financial support from U.S. Department of Agriculture McIntire-Stennis project number MO-NRSL0893 and a Frieda Yeo Fellowship at the University of Missouri. The publication is not intended to reflect the opinions of these institutions. Any errors remain the responsibility of the authors. The authors also acknowledge with appreciation the suggestions of Prof. Francisco X. Aguilar in shaping the manuscript. We wish to also thank the anonymous reviewers.

\section{References}

Aguilar, F. X., \& Cai, Z. (2010). Conjoint effect of environmental labeling, disclosure of forest of origin and price on consumer preferences for wood products in the US and UK. Ecological Economics, 70, 308-316. https://doi.org/10.1016/j.ecolecon.2010.09.002

Aguilar, F. X., Cai, Z., \& Butler, B. (2017). Proximal Association of Land Management Preferences: Evidence from Family Forest Owners. PLOS One, 12, e0169667. https://doi.org/10.1371/journal.pone.0169667

Aguilar, F. X., Obeng, E. A., \& Cai, Z. (2018). Water quality improvements elicit consistent willingness-to-pay for the enhancement of forested watershed ecosystem services. Ecosystem Services, 30, 158-171. https://doi.org/10.1016/j.ecoser.2018.02.012

Ajzen, I. (1989). Attitude structure and behavior. In S. J. Breckler, \& A. G. Greenwald (Eds.), Attitude structure and function(pp. 241-284). New York: Springer

Ajzen, I. (1991). The theory of planned behavior. Organizational Behaviour and Human Decision Processes, 50, 179-211. https://doi.org/10.1016/0749-5978(91)90020-T

Ajzen, I., \& Peterson, G. L. (Eds.). (1988). Contingent value measurement: The price of everything and the value of nothing. Amenity resource valuation: Integrating economics with other disciplines. State College, PA: Venture, 65-75.

Alix-Garcia, J. M., Shapiro, E. N., \& Sims, K. R. (2012). Forest conservation and slippage: Evidence from Mexico's national payments for ecosystem services program. Land Economics, 88, 613-638. https://doi.org/10.3368/le.88.4.613

Amponin, J.A., Bennagen, E., Hess, S., \&Dela Cruz, J. (2007). Willingness to pay for watershed protection by domestic water users in Tuguegarao City, Philippines. Poverty Reduction and Environmental Management (PREM) Working Paper7 (06), 2007-06.

Arrow, K., Solow, R., Portney, P., Leaer, E., Radner, R., \& Schuman, H. (1993). Report of the NOAA Panel on Contingent Valuation. Federal Register 58: 4602-614.

Asare, M. (2015). Using the theory of planned behavior to determine the condom use behavior among college students. American Journal of Health Studies, 30, 43.

Bishop, M. M., \& Barber, N. A. (2015). Should I pay more? The relationship between normative beliefs and willingness-to-pay for organic and local products. The Journal of Marketing Theory and Practice, 23, 94-106. https://doi.org/10.1080/10696679.2015.980182

Blumenschein, K., Blomquist, G. C., Johannesson, M., Horn, N., \& Freeman, P. (2008). Eliciting willingness to pay without bias: evidence from a field experiment. Journal of Economics, 118, 114-137. https://doi.org/10.1111/j.1468-0297.2007.02106.x

Bond, I., Grieg-Gran, M., Wertz-Kanounnikoff, S., Hazlewood, P., Wunder, S., \& Angelsen, A. (2009). Incentives to sustain forest ecosystem services: a review and lessons for REDD. Natural Resource Issues No. 16. International Institute for Environment and Development, London with CIFOR, Bogor, Indonesia and World Resource Institute, Washinton D.C., 47p. 
Botetzagias, I., Dima, A. F., \& Malesios, C. (2015). Extending the theory of planned behavior in the context of recycling: The role of moral norms and of demographic predictors. Resources, Conservation and Recycling, 95, 58-67. https://doi.org/10.1016/j.resconrec.2014.12.004

Brown, T., Champ, P., Bishop, R., \& McCollum, D. (1996). Which Response Format Reveals the Truth about Donations to a Public Good?Land Economics, 72, 152-66. https://doi.org/10.2307/3146963

Buchanan, E. A., \& Hvizdak, E. E. (2009). Online survey tools: ethical and methodological concerns of human research ethics committees. Journal of Empirical Research on Human Research Ethics, 4, 37-48. https://doi.org/10.1525/jer.2009.4.2.37

Calder, I. R., \& Aylward, B. (2006). Forest and floods: moving to an evidence-based approach to watershed and integrated flood management. Water International, 31, 1-13. https://doi.org/10.1080/02508060608691918

Calder, I. R., Smyle, J., \& Aylward, B. (2007). Debate over flood-proofing effects of planting forests. Nature, 450, 945. https://doi.org/10.1038/450945b

Champ, P. A., \& Bishop, R. C. (2001). Donation payment mechanisms and contingent valuation: an empirical study of Hypothetical Bias. Environmental and Resource Economics, 19, 383-402. https://doi.org/10.1023/A:1011604818385

Champ, P., Bishop, R., Brown, T., \& McCollum D. (1994) Some Evidence Concerning the Validity of Contingent Valuation: Preliminary Results of an Experiment. In R. Ready (Ed.), Seventh Interim Report W-133, Benefits and Costs Transfer in Natural Resources Planning(pp. 187-218). Dept. of Agr. Econ., University of Kentucky, Lexington KY, 1994.

Chichilnisky, G., \& Heal, G. (1998). Economic returns from the biosphere. Nature, 391, 629-630. https://doi.org/10.1038/35481

Clark, C. F., Kotchen, M. J., \& Moore, M. R. (2003). Internal and external influences on proenvironmentalbehavior: participation in a green electricity program. Journal of Environmental Psychology, 23, 237-246. https://doi.org/10.1016/S0272-4944(02)00105-6

Colombo, S., Hanley, N., \&Louviere, J. (2009). Modeling preference heterogeneity in stated choice data: an analysis for public goods generated by agriculture. Agricultural Economics,40, 307-322. https://doi.org/10.1111/j.1574-0862.2009.00377.x

Cronbach, L. J., \& Shavelson, J. R. (2004). My current thoughts on coefficient alpha and successor procedures. Educational and Psychological Measurement, 64, 391-418. https://doi.org/10.1177/0013164404266386

Dalrymple, C.J., Peterson, M.N., Cobb, D.T., Sills, E.O., Bondell, H.D., \&Dalrymple, D.J. (2012). Estimating public willingness to fund nongame conservation through state tax initiatives. Wildlife Society Bulletin,36, 483-491. https://doi.org/10.1002/wsb.164

Denscombe, M. (2006). Web-based questionnaires and the mode effect: An evaluation based on completion rates and data contents of near-identical questionnaires delivered in different modes. Social Science Computer Review, 24, 246-254. https://doi.org/10.1177/0894439305284522

Dillman, D. A., Smyth, J. D., \& Christian, L. (2014). Internet, Phone, Mail, and Mixed-Mode Surveys: The Tailored Design Method. John Wiley and Sons, Hoboken, NJ, p. 528.

Dolnicar, S., Laesser, C., \& Matus, K. (2009). Online versus paper format effects in tourism surveys. Journal of Travel Research, 47, 295-316. https://doi.org/10.1177/0047287508326506

Donald, J., Weir, I., Bonnett, S., Maxfield, P., \& Ellwood, M. F. (2018). The relative importance of invertebrate and microbial decomposition in a rainforest restoration project. Restoration Ecology, 26, 220-226. https://doi.org/10.1111/rec.12553

Emanuel, A. S., McCully, S. N., Gallagher, K. M., \& Updegraff, J. A. (2012). Theory of Planned Behavior explains gender difference in fruit and vegetable consumption. Appetite, 59, 693-697. https://doi.org/10.1016/j.appet.2012.08.007

Ernst, C., Gullick, R., \& Nixon, K. (2004). Conserving forests to protect water. Journal-American Water Works Association, 30, 1-7. https://doi.org/10.1002/j.1551-8701.2004.tb01752.x

Fielding, K. S., McDonald, R., \& Louis, W. R. (2008). Theory of planned behavior, identity and intentions to engage in environmental activism. Journal of Environmental Psychology, 28, 318-326. https://doi.org/10.1016/j.jenvp.2008.03.003 
Food and Agriculture Organization. (2015). Global forest resources assessment 2015. How are the world's forests changing? FAO, Rome. Retrieved September 15, 2018, from http://www.fao.org/3/a-i4793e.pdf

Garber-Yonts, B., Kerkvliet, J., \& Johnson, R. (2004). Public values for biodiversity conservation policies in the Oregon Coast Range. Forest Science, 50, 589-602.

Giraud, K. L., Loomis, J. B., \& Johnson, R. L. (1999). Internal and external scope in willingness-to-pay estimates for threatened and endangered wildfire. Journal of Environmental Management, 56, 221-229. https://doi.org/10.1006/jema.1999.0277

Haab, T. C., Interis, M. G., Petrolia, D. R., \& Whitehead, J. C. (2013). From hopeless to curious? Thoughts on Hausman's "dubious to hopeless" critique of contingent valuation. Applied Economic Perspectives and Policy, 35, 593-612. https://doi.org/10.1093/aepp/ppt029

Hack, J., Kosmus, M., Kräuter, H., \& Somarriba, D. (2013). Payments for hydrological Ecosystem Services in the Gil González Watershed-A Public-Private-Partnership Case Study. Retrieved March 3, 2017, from https://www.cbd.int/financial/pes/nicaraguapeshydro.pdf

Hamilton, S. F., Sunding, D. L., \& Zilberman, D. (2003). Public goods and the value of product quality regulations: the case of food safety. Journal of Public Economics, 87, 799-817. https://doi.org/10.1016/S0047-2727(01)00103-7

Han, Y., \&Hansen, H. (2012). Determinants of Sustainable Food Consumption: A Meta-Analysis Using a Traditional and a Structural Equation Modelling Approach. International Journal of Psychological Studies, 4, 22. https://doi.org/10.5539/ijps.v4n1p22

Hanemann, W. M. (1984). Welfare evaluations in contingent valuation experiments with discrete responses. American Journal of Agricultural Economics, 66, 332-341. https://doi.org/10.2307/1240800

Harris, C. C., Driver, B. L., \& McLaughlin, W. J. (1989). Improving the contingent valuation method: a psychological perspective. Journal of Environmental Economics and Management, 17, 213-229. https://doi.org/10.1016/0095-0696(89)90017-X

Hausman, J. (2012). Contingent valuation: from dubious to hopeless. Journal of Economic Perspectives, 26(4), 43-56. https://doi.org/10.1257/jep.26.4.43

Houghton, R.A. (2005). Aboveground forest biomass and the global carbon balance. Global Change Biology, 11, 945-958. https://doi.org/10.1111/j.1365-2486.2005.00955.x

Hu, W., Batte, M. T., Woods, T., \& Ernst, S. (2011). Consumer preferences for local production and other value-added label claims for a processed food product. European Review of Agricultural Economics,39, 489-510. https://doi.org/10.1093/erae/jbr039

Jensen, K. L., Clark, C. D., English, B. C., Menard, R. J., Skahan, D. K., \& Marra, A. C. (2010). Willingness to pay for E85 from corn, switchgrass, and wood residues. Energy Economics, 32, 1253-1262. https://doi.org/10.1016/j.eneco.2010.06.002

Johnston, R. J., Boyle, K. J., Adamowicz, W., Bennett, J., Brouwer, R., Cameron, T. A., ... Tourangeau, R. (2017). Contemporary guidance for stated preference studies. Journal of the Association of Environmental and Resource Economists, 4, 319-405. https://doi.org/10.1086/691697

Jonathan, C., Onyekwelu1, J. C., Reinhard, M., \& Bernd, S. (2007). Tree species diversity and soil status of two natural forest ecosystems in lowland humid tropical rainforest region of Nigeria. A paper presented at the Conference on International Agricultural Research for Development (Tropentag), University of Kassel-Witzenhausen and University of Göttingen. October 9-11, 2007. Retrieved March 3, 2017, from http://w3.forst.tu-muenchen.de/ waldbau/litorg0/2020.pdf

Kang, K. H., Stein, L., Heo, C. Y., \& Lee, S. (2012). Consumers' willingness to pay for green initiatives of the hotel industry. International Journal of Hospitality Management, 31, 564-572. https://doi.org/10.1016/j.ijhm.2011.08.001

Kramer, R. A., \& Mercer, D. E. (1997). Valuing a global environmental good: US residents' willingness to pay to protect tropical rain forests. Land Economics, 196-210. https://doi.org/10.2307/3147282

Kreye, M. M., Adams, D. C., \& Escobedo, F. J. (2014). The value of forest conservation for water quality protection. Forests, 5, 862-884. https://doi.org/10.3390/f5050862

Leggett, C. G., Kleckner, N. S., Boyle, K. J., Dufield, J. W., \&Mitchell, R. C. (2003). Social desirability bias in 
contingent valuation surveys administered through in-person interviews. Land Economics, 79, 561-575. https://doi.org/10.2307/3147300

Liebe, U., Preisendörfer, P., \& Meyerhoff, J. (2011). To pay or not to pay: Competing theories to explain individuals' willingness to pay for public environmental goods. Environment and Behaviour, 43, 106-130. https://doi.org/10.1177/0013916509346229

Lo, A. Y., \& Jim, C. Y. (2010). Willingness of residents to pay and motives for conservation of urban green spaces in the compact city of Hong Kong. Urban Forestry \& Urban Greening, 9, 113-120. https://doi.org/10.1016/j.ufug.2010.01.001

Loomis, J., \& Ekstrand, E. (1997). Economic benefits of critical habitat for the Mexican spotted owl: a scope test using a multiple-bounded contingent valuation survey. Journal of Agricultural and Resource Economics, 356-366.

López-Mosquera, N. (2016). Gender differences, theory of planned behavior and willingness to pay. Journal of Environmental Psychology, 45, 165-175. https://doi.org/10.1016/j.jenvp.2016.01.006

López-Mosquera, N., \& Sánchez, M. (2012). Theory of Planned Behavior and the Value-Belief-Norm Theory explaining willingness to pay for a suburban park. Journal of Environmental Management, 113, $251-262$. https://doi.org/10.1016/j.jenvman.2012.08.029

Lorenzo, A. B., Blanche, C. A., Qi, Y., \& Guidry, M. M. (2000). Assessing residents' willingness to pay to preserve the community urban: a small-city case study. Journal of Aboriculture, 26, 319-325.

McAfee, K. (2012). The contradictory logic of global ecosystem services markets. Development and Change, 43, 105-131. https://doi.org/10.1111/j.1467-7660.2011.01745.x

Meldrum, J. R. (2015). Comparing different attitude statements in latent class models of stated preferences for managing an invasive forest pathogen. Ecological Economics, 120, 13-22. https://doi.org/10.1016/j.ecolecon.2015.09.024

Millennium Ecosystem Assessment. (2005). Ecosystems and Human Well-being: Current State and Trends. Island Press, Washington, DC.

Mitchell, R. C., \& Carson, R. T. (1989). Using Surveys to Value Public Goods: the Contingent Valuation Method. Resources for the Future, Washington, DC.

Mohebalian, P. M., \& Aguilar, F. X. (2016). Additionality and design of forest conservation programs: Insights from Ecuador's Socio Bosque Program. Forest Policy and Economics, 71, 103-114. https://doi.org/10.1016/j.forpol.2015.08.002

Mohebalian, P.M., \&Aguilar, F.X. (2018). Beneath the canopy: tropical forests enrolled in conservation payments reveal evidence of less degradation. Ecological Economics, 143, 64-73. https://doi.org/10.1016/j.ecolecon.2017.06.038

Moreno-Sanchez, R., Maldonado, J. H.,Wunder, S., \& Borda-Almanza, C. (2012). Heterogeneous users and willingness to pay in an ongoing payment for watershed protection initiative in the Colombian Andes. Ecological Economics, 75, 126-134. https://doi.org/10.1016/j.ecolecon.2012.01.009

Morrison, M. D., Blamey, R. K., \& Bennett, J. W., (2000). Minimising payment vehicle bias in contingent valuation studies. Environmental and Resource Economics, 16, 407-422. https://doi.org/10.1023/A:1008368611972

Mueller, J. M. (2014). Estimating willingness to pay for watershed restoration in Flagstaff, Arizona using dichotomous-choice contingent valuation. Forestry, 87, 327-333. https://doi.org/10.1093/forestry/cpt035

Ninan, K.N. (2014). Valuing Ecosystem Services: Methodological Issues and Case Studies. Edward Elgar Publishing, Cheltenham, U.K. https://doi.org/10.4337/9781781955161

Obeng, A. E. (2017). Social preferences and willingness-to-pay for forest ecosystem services: implications for payments for ecosystem services schemes. Doctoral Dissertation. University of Missouri, USA.

Obeng, E. A., \& Aguilar, F. X. (2015). Marginal effects on biodiversity, carbon sequestration and nutrient cycling of transitions from tropical forests to cacao farming systems. Agroforestry Systems, 89, 19-35. https://doi.org/10.1007/s10457-014-9739-9

Obeng, E. A., \& Aguilar, F. X. (2018). Value orientation and payment for ecosystem services: Perceived detrimental consequences lead to willingness-to-pay for ecosystem services. Journal of Environmental 
Management, 206, 458-471. https://doi.org/10.1016/j.jenvman.2017.10.059

Obeng, E. A., Aguilar, F. X., \& Mccann, L. M. (2018). Payments for forest ecosystem services: a look at neglected existence values, the free-rider problem and beneficiaries' willingness to pay. International Forestry Review, 20, 206-219. https://doi.org/10.1505/146554818823767528

Pagiola, S. (2008). Payments for environmental services in Costa Rica. Ecological Economics, 65, 712-724. https://doi.org/10.1016/j.ecolecon.2007.07.033

Pascual, U., Muradian, R., Brander, L., Gómez-Baggethun, E., Martín-López, B., Verma, M., ... Farley, J. (2010). The economics of valuing ecosystem services and biodiversity.TEEB-Ecological and Economic Foundation. Retrieved September 6, 2018, from http://doc.teebweb.org/wp-content/uploads/2013/04/D0-Chapter-5-The-economics-of-valuing-ecosystem-se rvices-and-biodiversity.pdf

Pearce, D. W. (2001). The economic value of forest ecosystems. Ecosystem Health, 7, 284-296. https://doi.org/10.1046/j.1526-0992.2001.01037.x

Pew Research Center. (2017). After Seismic Political Shift, Modes Changes in Public's Policy Agenda: More view the environment, foreign trade as top policy priorities. Retrieved September 6, 2018, from http://www.people-press.org/wp-content/uploads/sites/4/2017/01/1-24-17-Priorities release.pdf

Poe, G., \& Welsh, M. (1995). WTP Certainty Intervals and the Disparity between Contingent Valuation Elicitation Formats. In D. Larson (Ed.), Eighth Interim Report W-133, Benefits and Costs in Natural Resources Planning(pp. 271-300). Dept. of Agr. Econ., University of California.

Polasky, S., Gainutdinova, O., \& Kerkvliet, J. (1996). Comparing CV Responses with Voting Behavior: Open SpaceSurvey and Referendum in Corvallis, Oregon. In J. Herriges (Ed.), Ninth Interim Report W-133, Benefits and Costs Transferin Natural Resources Planning (pp. 105-30). Dept of Econ., Iowa State University.

Postel, S. L., \& Thompson Jr, B. H. (2005). Watershed protection: Capturing the benefits of nature's water supply services. In Nat. Resour. Forum, pp. 98-108. Oxford, UK: Blackwell Publishing, Ltd. https://doi.org/10.1111/j.1477-8947.2005.00119.x

Presnall, C., L_opez-Hoffman, L., \& Miller, M. L. (2015). Adding ecosystem services to environmental impact analyses: more sequins on a "bloated Elvis" or rockin' idea? Ecological Economics, 115, 29-38. https://doi.org/10.1016/j.ecolecon.2014.02.001

Ready, R. C., Whitehead, J. C., \& Blomquist, G. C. (1995). Contingent valuation when respondents are ambivalent. Journal of Environmental Economics and Management, 29, 181-196. https://doi.org/10.1006/jeem.1995.1040

Ready, R., Whitehead, J., \& Blomquist, G. (1995). Contingent Valuation When Respondents Are Ambivalent. Journal of Environmental Economics and Management, 29, 181-97. https://doi.org/10.1006/jeem.1995.1040

Rekola, E. P. M. (2001). The theory of planned behavior in predicting willingness to pay for abatement of forest regeneration. Society and Natural Resources, 14, 93-106. https://doi.org/10.1080/089419201300000517

Revelt, D., \& Train, K. (1998). Mixed Logit with repeated choices: Households' choices of appliance efficiency level. The Review of Economics and Statistics, 80, 647-657. https://doi.org/10.1162/003465398557735

Robalino, J., \& Pfaff, A. (2013). Ecopayments and deforestation in Costa Rica: A nationwide analysis of PSA's initial years. Land Economics, 89, 432-448. https://doi.org/10.3368/le.89.3.432

Roesch-McNally, G. E., \& Rabotyagov, S. S. (2016). Paying for forest ecosystem services: voluntary versus $\begin{array}{llll}\text { mandatory } & \text { payments. }\end{array}$ https://doi.org/10.1007/s00267-015-0641-7

Ryan, A. M., \& Spash, C. L. (2010). Measuring Beliefs Supportive of Environmental Action and Inaction: a Reinterpretation of the Awareness of Consequences Scale. Research Papers in Economics, Munich. Paper No. 23900. $\quad$ Retrieved September30, 2018, fromhttps://mpra.ub.unimuenchen.de/23900/1/MPRA_paper_23900.pdf

Ryan, S., \& Carr, A. (2010). Applying the biopsychosocial model to the management of rheumatic disease. In Rheumatology (pp. 63-75). Churchill Livingstone. https://doi.org/10.1016/B978-0-443-06934-5.00005-X 
Schahn, J., \& Holzer, E. (1990). Studies of individual environmental concern: The role of knowledge, gender, and background variables. Environment and Behaviour, 22, 767-786. https://doi.org/10.1177/0013916590226003

Spash, C., Urama, K., Burton, R., Kenyon, W., Shannon, P., \& Hill, G. (2009). Motives behind willingness to pay for improving biodiversity in water ecosystems: economics, ethics and social psychology. Ecol. Econ., 68, 955-964. https://doi.org/10.1016/j.ecolecon.2006.09.013

Stubbs, M. (2014). Conservation Reserve Program (CRP): status and issues. Congressional Research Service Report, 42783, 24 pp. Retrieved December 7, 2016, from http://www.nationalaglawcenter.org/wp-content/uploads/assets/crs/R42783.pdf

Thøgersen, J., \& Ölander, F. (2006). To what degree are environmentally beneficial choices reflective of a general conservation stance? Environment and Behaviour, 38, 550-569. https://doi.org/10.1177/0013916505283832

Tindall, D. B., Davies, S., \& Mauboules, C. (2003). Activism and conservation behavior in an environmental movement: The contradictory effects of gender. Society and Natural Resources, 16, 909-932. https://doi.org/10.1080/716100620

United Nations Framework Convention on Climate Change (UNFCCC). (2007). Report of the Conference of the Parties on its thirteenth session, held in Bali from 3 to 15 December 2007.Retrieved December 17, 2018, from http://unfccc.int/resource/docs/2007/cop13/eng/06a01.pdf

United Nations Framework Convention on Climate Change (UNFCCC). (2007). The Kyoto Protocol mechanisms. Retrieved December 15, 2018, fromhttp://unfccc.int/resource/docs/2011/sbi/eng/inf02.pdf

United States Census Bureau. (2015). Current population survey, 2015 annual social and economic supplement. Retrieved September 17, 2018, from https://www.census.gov/programs-surveys/cps.html

Van Houtven, G., Mansfield, C., Phaneuf, D. J., von Haefen, R., Milstead, B., Kenney, M. A., \& Reckhow, K. H. (2014). Combining expert elicitation and stated preference methods to value ecosystem services from $\begin{array}{lllll}\text { improved lake water quality. Ecological Economics, } & \text { 99, }\end{array}$ https://doi.org/10.1016/j.ecolecon.2013.12.018

Vásquez-Lavín, F., Ibarnegaray, V., Ponce Oliva, R., \&Hernández Hernández, J. (2016). Payment for Ecosystem Services in the Bolivian Sub-Andean Humid Forest. The Journal of Environment \& Development,25, 306-331. https://doi.org/10.1177/1070496516655838

Venkatachalam, L. (2004). The contingent valuation method: a review. Environmental Impact Assessment Review, 24(1), 89-124. https://doi.org/10.1016/S0195-9255(03)00138-0

Vincent, J. R., Carson, R. T., DeShazo, J. R., Schwabe, K. A., Ahmad, I., Chong, S. K., ... Potts, M. D. (2014). Tropical countries may be willing to pay more to protect their forests. Proceedings of the National Academy of Sciences $111 \mathrm{pp}: 10113-10118$. https://doi.org/10.1073/pnas.1312246111

Welsh, M., \& Bishop, R. (1993) Multiple-Bounded Discrete Choice Models. In J. Bergstrom (Ed.), Sixth Interim Report W-133, Benefits and Costs Transfers in Natural Resources Planning (pp. 331-52). Department of Agricultural Economics, University of Georgia.

Wiser, R. H. (2007). Using contingent valuation to explore willingness to pay for renewable energy: a comparison of collective and voluntary payment vehicles. Ecological Economics, 62, 419-432. https://doi.org/10.1016/j.ecolecon.2006.07.003

Wunder, S. (2001). Poverty alleviation and tropical forests—what scope for synergies?World Development, 29 , 1817-1833. https://doi.org/10.1016/S0305-750X(01)00070-5

Wunder, S. (2005). Payments for environmental services: some nuts and bolts. CIFOR Occasional Paper no. 42. Retrieved September 17, 2018, from http://www.cifor.org/publications/pdf_files/occpapers/op-42.pdf

Wunder, S. (2015). Revisiting the concept of payments for environmental services. Ecological Economics, 117, 234-243. https://doi.org/10.1016/j.ecolecon.2014.08.016 


\section{Appendix}

Appendix A.Correlation among variables used in the model analysis

\begin{tabular}{|c|c|c|c|c|c|c|c|c|c|c|}
\hline Variable & WTP & Cost & Subnorm & Att_res & Pbcontrol & Female & Age & $\begin{array}{l}\text { College } \\
\text { education }\end{array}$ & $\begin{array}{l}\text { Visit } \\
\text { experience }\end{array}$ & $\begin{array}{l}\text { Support_ENV } \\
\text { group }\end{array}$ \\
\hline WTP & 1.000 & & & & & & & & & \\
\hline Cost & -0.244 & 1.000 & & & & & & & & \\
\hline Subnorm & 0.382 & $<0.001$ & 1.000 & & & & & & & \\
\hline Att_res & 0.166 & $<0.001$ & 0.426 & 1.000 & & & & & & \\
\hline Pbcontrol & 0.276 & $<0.001$ & 0.789 & 0.356 & 1.000 & & & & & \\
\hline Female & -0.098 & $<0.001$ & -0.087 & 0.049 & -0.045 & 1.000 & & & & \\
\hline Age & -0.118 & $<0.001$ & -0.085 & 0.047 & -0.024 & -0.054 & 1.000 & & & \\
\hline $\begin{array}{l}\text { College } \\
\text { education }\end{array}$ & 0.133 & $<0.001$ & 0.128 & 0.078 & 0.105 & -0.127 & 0.072 & 1.000 & & \\
\hline $\begin{array}{l}\text { Visit } \\
\text { experience }\end{array}$ & 0.201 & $<0.001$ & 0.202 & 0.095 & 0.098 & -0.140 & 0.029 & 0.231 & 1.000 & \\
\hline $\begin{array}{l}\text { Support_ENV } \\
\text { group }\end{array}$ & 0.273 & $<0.001$ & 0.267 & 0.077 & 0.161 & -0.149 & -0.053 & 0.162 & 0.252 & 1.000 \\
\hline
\end{tabular}

Appendix B.Variance inflation factor index to examine multicollinearity

\begin{tabular}{|l|c|c|}
\hline Variable & VIF & $\mathbf{1 / V I F}$ \\
\hline Subnorm & 3.120 & 0.320 \\
\hline Pbcontrol & 2.710 & 0.369 \\
\hline Att_res & 1.250 & 0.801 \\
\hline Support_Env & 1.160 & 0.864 \\
\hline Visit_experience & 1.150 & 0.870 \\
\hline College education & 1.090 & 0.918 \\
\hline Female & 1.060 & 0.945 \\
\hline Age & 1.040 & 0.966 \\
\hline Price & 1.000 & 1.000 \\
\hline Mean VIF & 1.510 & \\
\hline
\end{tabular}

\section{Copyrights}

Copyright for this article is retained by the author(s), with first publication rights granted to the journal.

This is an open-access article distributed under the terms and conditions of the Creative Commons Attribution license (http://creativecommons.org/licenses/by/4.0/). 